www.jmscr.igmpublication.org Impact Factor 5.244

Index Copernicus Value: 83.27

ISSN (e)-2347-176x ISSN (p) 2455-0450

crossref DOI: _https://dx.doi.org/10.18535/jmscr/v4i10.112

\title{
Study of Coagulation Profile in Patients of Pregnancy Induced Hypertension-A Single Centric Prospective Study
}

\author{
Authors \\ Shweta Chaudhary ${ }^{1 *}$, Seema Baxi \\ ${ }^{1}$ Resident,Department of Pathology, Government Medical College, Bhavnagar, INDIA \\ ${ }^{2}$ Additional Professor, Department of Pathology, Government Medical College, Bhavnagar, INDIA \\ *Corresponding Author \\ Dr Shweta B. Chaudhary \\ $3^{\text {rd }}$ year Resident Department of Pathology Govt. Medical College, Bhavnagar-364001 \\ Email: dr.shwetachaudhary.062@gmail.com
}

\begin{abstract}
Background: Present study was done to study the abnormalities in platelet, PT (prothrombin time) and APTT (activated partial thromboplastin time) in patients of PIH, to compare them with the results of normal pregnant females of $3^{\text {rd }}$ trimester and to correlate them with the severity of PIH.

Materials and Methods: 100 normotensive and 100 hypertensive $3^{\text {rd }}$ trimester pregnant females formed the control and study group respectively. Platelet count, PT and APTT were performed by automatic analyzers.

Results: Comparison between study and control group showed statistically significant $(p<0.001)$ decrease in platelet count and increase in PT and APTT. Platelet count significantly decreased $(p<0.05)$ with increasing severity except between gestational hypertension and mild preeclampsia. There is high prevalence of thrombocytopenia in preeclampsia (57\%) and eclampsia (100\%) cases. PT and APTT were prolonged only in cases of severe preeclampsia and eclampsia with platelet count $<1$ lac/cmm. Prolonged PT was seen in $28 \%$ and $37.5 \%$ cases and prolonged APTT in $2.8 \%$ and $25 \%$ cases of severe preeclampsia and eclampsia respectively.

Conclusion: Significant thrombocytopenia is seen in PIH and degree increases with increasing severity. $P T$ and APTT are also increased significantly in study group but do not differ with severity and are seen to be prolonged only in cases of thrombocytopenia. Mean PT and APTT fall in normal reference range in all groups, but increase from lower to upper normal limit as severity increases.

Keywords: Pregnancy induced hypertension, PT, APTT, Platelet count.
\end{abstract}

\section{INTRODUCTION}

Pregnancy induced hypertension (PIH) is a common medical disorder of pregnancy, that often results in multi-organ failure and contributes greatly to the maternal morbidity and mortality rates ${ }^{[1]}$.

Profound changes in the coagulation and fibrinolytic system occur during normal pregnancy causing a hypercoagulable state ${ }^{[2]}$. In preeclampsia and eclampsia there is evidence of disseminated intravascular coagulopathy (DIC) affecting widespread organs of the body occurs as opposed to selective DIC only at the placental site in normal pregnancy. This process appears to be initiated by the release of thromboplastin into the circulation. There is reduction of platelets and 
degree of thrombocytopenia reflects the severity of pathology. There is also reduction of fibrinogen, antithrombin III and plasminogen level in the blood ${ }^{[1]}$.

The underlying coagulation abnormality increases the risk of bleeding complications, especially during operative delivery and during the placement of an epidural catheter for regional anaesthesia. Anticipation of these coagulation disturbances in patients of pre-eclampsia can prevent significant maternal morbidity and mortality. Early assessment of severity of PIH is necessary to prevent complications like HELLP (Hemolysis, Elevated Liver enzymes, Low Platelet count) syndrome ${ }^{[2]}$.

Hypertension prior to 20 weeks gestation almost always is due to chronic hypertension; preeclampsia is rare prior to the third trimester ${ }^{[2]}$. Hence this study was done to study the platelet and coagulation abnormalities occurring in patients of PIH including platelet count, PT and APTT parameters.

\section{MATERIALS AND METHODS}

A prospective comparative study of 100 females with uncomplicated pregnancy and 100 females with pregnancy induced hypertension from Obstetrics and Gynaecology Department was conducted in the Department of Pathology of a teaching institute during the period of September 2015 to May 2016.

Control Group: This group comprised of pregnant women in $3^{\text {rd }}$ trimester with normal blood pressure, no proteinuria or edema.

Study Group: This group comprised of pregnant women with blood pressure at or above 140/90 $\mathrm{mm}$ of $\mathrm{Hg}$ on at least two occasions, six or more hours apart in $3^{\text {rd }}$ trimester of the current pregnancy together with or without proteinuria, edema, convulsions and coma. Study group further classified in gestational hypertension, preeclampsia: mild and severe and eclampsia depending on their presentation.
Platelet count was done by automated cell counter Cell dyne and PT and APTT were done on fully automated Stago STA Compact.

All statistical analysis was done by using graphpad and SPSS trial version 22 software.

\section{RESULTS}

A total of 200 pregnant females were included in the study, out of which 100 were controls and 100 were in study group. Distribution according to age and diagnosis as follows.

Table 1: Distribution of cases according to age and diagnosis

\begin{tabular}{|l|l|l|l|l|l|l|}
\hline $\begin{array}{l}\text { Age in } \\
\text { years }\end{array}$ & $\begin{array}{l}\text { Control } \\
\text { group } \\
(100)\end{array}$ & $\begin{array}{l}\text { Study } \\
\text { group } \\
(100)\end{array}$ & $\begin{array}{l}\text { GHT } \\
(17)\end{array}$ & $\begin{array}{l}\text { MP } \\
(40)\end{array}$ & $\begin{array}{l}\text { SP } \\
(35)\end{array}$ & $\begin{array}{l}\text { E } \\
(8)\end{array}$ \\
\hline $18-23$ & 24 & 31 & 02 & 17 & 08 & 04 \\
\hline $24-29$ & 53 & 47 & 09 & 18 & 16 & 04 \\
\hline $30-35$ & 22 & 19 & 04 & 04 & 11 & 0 \\
\hline$>35$ & 01 & 03 & 02 & 01 & 0 & 0 \\
\hline Total & 100 & 100 & 17 & 40 & 35 & 8 \\
\hline
\end{tabular}

GHT=gestational hypertension; $\mathrm{MP}=$ mild preeclampsia; $\mathrm{SP}=$ severe preeclampsia; $\mathrm{E}=$ eclampsia

Maximum number of cases in both the groups, control and study group are between 18 to 29 years of age.

Table 2: Distribution of cases according to parity.

\begin{tabular}{|c|c|c|}
\hline Parity & Control group \% & Study group \% \\
\hline Primipara & 43 & 64 \\
\hline Multipara & 57 & 36 \\
\hline
\end{tabular}

In the present study PIH was more common in primipara.

Mean values of platelet count, PT and APPT of control and study group and individual group are as shown in table 3 and 4 . Mean values of PT and APTT fall in normal reference range in all groups, but when compared with increasing grade of severity it shows gradual increase. Decrease in platelet count is statistically significant $(\mathrm{p}<0.001)$. There is statistically significant increase in PT $(\mathrm{p}<0.001)$ and APTT $(\mathrm{p}<0.001)$ when compared between study and control group using unpaired $\mathrm{T}$ test (table 3). 
Table 3: Comparison of platelet count, PT and APTT between control and overall values of study group

\begin{tabular}{|c|c|c|c|c|}
\hline & $\begin{array}{c}\text { Control group } \\
(100)\end{array}$ & $\begin{array}{c}\text { Study group } \\
(100)\end{array}$ & $\begin{array}{c}\text { P value } \\
\text { (unpaired } \\
\text { t test })\end{array}$ & Significance \\
\hline $\begin{array}{c}\text { PlateletCount } \\
\left(\text { lac/mm } \text { m }^{3}\right.\end{array}$ & $3.11 \pm 2.49$ & $1.91 \pm 0.88$ & $<0.001$ & Significant \\
\hline $\begin{array}{c}\text { PT } \\
\text { (seconds) }\end{array}$ & $12.70 \pm 0.96$ & $15.18 \pm 5.04$ & $<0.001$ & Significant \\
\hline $\begin{array}{c}\text { APTT } \\
\text { (seconds) }\end{array}$ & $26.59 \pm 1.88$ & $31.25 \pm 5.04$ & $<0.001$ & Significant \\
\hline
\end{tabular}

Table 4: Mean values of platelet count, PT and APTT with individual categories of study group.

\begin{tabular}{|c|c|c|c|c|c|}
\hline & $\begin{array}{c}\text { Control } \\
\text { group }\end{array}$ & $\begin{array}{c}\text { GHT } \\
\text { (group1) }\end{array}$ & $\begin{array}{c}\text { MP } \\
\text { (group 2) }\end{array}$ & $\begin{array}{c}\text { SP } \\
\text { (group 3) }\end{array}$ & $\begin{array}{c}\text { E } \\
\text { (group 4) }\end{array}$ \\
\hline $\begin{array}{c}\text { PlateletCount } \\
\left(\text { lac/mm } \text { ( }^{3}\right.\end{array}$ & $3.12 \pm 2.49$ & $2.72 \pm 0.46$ & $2.35 \pm 0.54$ & $1.24 \pm 0.73$ & $0.86 \pm 0.46$ \\
\hline $\begin{array}{c}\text { PT } \\
\text { (seconds) }\end{array}$ & $12.70 \pm 0.96$ & $13.73 \pm 0.71$ & $14.23 \pm 0.98$ & $16.59 \pm 3.62$ & $16.81 \pm 2.15$ \\
\hline $\begin{array}{c}\text { APTT } \\
\text { (seconds) }\end{array}$ & $26.58 \pm 1.88$ & $28.84 \pm 1.59$ & $29.43 \pm 1.92$ & $32.48 \pm 5.01$ & $40.06 \pm 9.04$ \\
\hline
\end{tabular}

Table 5: Comparison of platelet count, PT and APTT of control with each group and between each study group.

\begin{tabular}{|c|c|c|c|c|}
\hline No. & & $\begin{array}{c}\text { Platelet Count } \\
(\mathrm{p} \text { value })\end{array}$ & $\begin{array}{c}\text { PT } \\
(\mathrm{p} \text { value })\end{array}$ & $\begin{array}{c}\text { APTT } \\
(\mathrm{p} \text { value })\end{array}$ \\
\hline 1 & Control vs GHT & $>0.05$ & $<0.05^{*}$ & $<0.05^{*}$ \\
\hline 2 & Control vs MP & $<0.05$ & $<0.05$ & $<0.05^{*}$ \\
\hline 3 & Control vs SP & $<0.05$ & $<0.05$ & $<0.05^{*}$ \\
\hline 4 & Control vs E & $<0.05$ & $<0.05^{*}$ & $<0.05$ \\
\hline 5 & GHT vs MP & $>0.05$ & $>0.05$ & $>0.05$ \\
\hline 6 & MP vs SP & $<0.05$ & $<0.05$ & $>0.05$ \\
\hline 7 & SP vs E & $<0.05$ & $>0.05$ & $<0.05$ \\
\hline 8 & GHT vs E & $<0.05$ & $<0.05$ & $<0.05$ \\
\hline
\end{tabular}

In table 5 results are statistically significant when $\mathrm{p}<0.05$. When coagulation parameters were compared between control group and each study group significant difference between all parameters was seen except the platelet count which showed no significant decrease in gestational hypertension as compared with control. Unpaired t test* and Mann Whitney (unstarred) tests were applied (no 1 to 4 ). When coagulation parameters were assessed in patients of PIH with increasing severity platelet count showed significant decrease with increasing severity except between gestational hypertension and mild preeclampsia.PT and APTT showed significant increase when compared between gestational hypertension and eclampsia but showed variable results between the other 2 subgroups as per ANOVA test by Bonferroni using SPSS trial version 22 software. (no 5 to 8 ).

Table 6: Degree of thrombocytopenia in the individual categories

\begin{tabular}{|c|c|c|c|c|c|c|}
\hline $\begin{array}{c}\text { PlateletCo } \\
\text { unt } \\
\left(\mathrm{lac} / \mathrm{mm}^{3}\right)\end{array}$ & $\begin{array}{c}\text { Control } \\
\text { group } \\
(100)\end{array}$ & $\begin{array}{c}\text { Study } \\
\text { group } \\
(100)\end{array}$ & $\begin{array}{c}\text { GHT } \\
(17)\end{array}$ & $\begin{array}{c}\text { MP } \\
(40)\end{array}$ & $\begin{array}{c}\text { SP } \\
(35)\end{array}$ & $\begin{array}{c}\text { E } \\
(8)\end{array}$ \\
\hline$<0.5$ & 0 & 9 & 0 & 0 & 7 & 2 \\
\hline $0.5-1$ & 0 & 11 & 0 & 0 & 9 & 2 \\
\hline $1-1.5$ & 01 & 11 & 0 & 3 & 4 & 4 \\
\hline$>1.5$ & 99 & 69 & 17 & 37 & 15 & 0 \\
\hline
\end{tabular}


Table 7: Coagulation abnormalities in subjects depending on platelet count in study group

\begin{tabular}{|c|c|c|c|c|}
\hline $\begin{array}{c}\text { PlateletCount } \\
(\text { lac/mm }\end{array}$ & \multicolumn{2}{|c|}{ PT } & \multicolumn{2}{c|}{ APTT } \\
\cline { 2 - 5 } & $\begin{array}{c}\text { Normal } \\
(87)\end{array}$ & $\begin{array}{c}\text { Prolonged } \\
(13)\end{array}$ & $\begin{array}{c}\text { Normal } \\
(97)\end{array}$ & $\begin{array}{c}\text { Prolonged } \\
(3)\end{array}$ \\
\hline$<0.5$ & 1 & 8 & 6 & 3 \\
\hline $0.5-1$ & 6 & 5 & 11 & 0 \\
\hline $1-1.5$ & 11 & 0 & 11 & 0 \\
\hline$>1.5$ & 69 & 0 & 69 & 0 \\
\hline & \multicolumn{2}{|c|}{$\begin{array}{c}\chi^{2} \text { value }=68.027 \\
\text { p value }<0.05 \\
\text { (significant) }\end{array}$} & $\begin{array}{c}\chi^{2} \text { value }=31.27 \\
\text { p value }<0.05 \\
\text { (significant) }\end{array}$ \\
\hline
\end{tabular}

Table 8: \% of cases showing abnormal values of platelet count, PT, APTT in each group

\begin{tabular}{|l|l|l|l|}
\hline & $\begin{array}{l}\text { Platelet } \\
\text { count }\end{array}$ & PT & APTT \\
\hline Control & $1 \%$ & $0 \%$ & $0 \%$ \\
\hline $\begin{array}{l}\text { mild } \\
\text { preeclampsia }\end{array}$ & $7.5 \%$ & $0 \%$ & $0 \%$ \\
\hline $\begin{array}{l}\text { severe } \\
\text { preeclampsia }\end{array}$ & $57 \%$ & $28 \%$ & $2.8 \%$ \\
\hline Eclampsia & $100 \%$ & $37.5 \%$ & $25 \%$ \\
\hline
\end{tabular}

Number of cases with low platelet count show increase with increasing severity of the PIH. (table 6) PT was prolonged only when platelet count was $<1$ lac and APTT was prolonged only with platelet count of $<0.5$ lac. However 6 cases of platelet count of $0.5-1$ lac and 1 case with $<0.05$ lac had normal PT. Similarly 6 cases of platelet $<0.5$ lac had normal APTT. These could not be explained. (table 7) Out of 13 prolonged PT results 10/35 were having severe preeclampsia while $3 / 8$ were diagnosed eclampsia and out of 3 prolonged APTT results $1 / 35$ was having severe preeclampsia and 2/8 cases had eclampsia. This suggests that increasing severity causes more deterioration of PT and APTT profile.

The above mentioned 3 cases with prolonged APTT also had prolonged PT in addition to thrombocytopenia.

Overall $31 \%$ cases of PIH showed thrombocytopenia, $13 \%$ had prolonged PT and 3\% had prolonged APTT.

\section{DISCUSSION}

The findings of the present study (64\%) and many other studies such as Leduc et al[3] (65\%) and Naaz A et al[4] (60\%), also confirm that PIH is more prevalent in primigravida. Maximum numbers of cases were between 18 to 29 years of age which is comparable with the studies of ShivkumarS [5], Prakash J [6], Priyadarshini

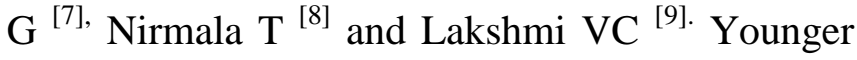
age of occurrence of PIH in these studies testify the early age of marriage and first pregnancy in this country compared to western countries.

There was fall in mean platelet count with increasing severity of PIH in present study. Reduction in platelet count can be attributed to platelet activation, platelet aggregation and platelet consumption which can be present during and even before the onset of disease. Platelet activation may lead to increase degeneration of thromboxane $\mathrm{A}_{2}$ and serotonin release, in turn increase vasoconstriction and platelet aggregation.

Table 9: Mean platelet count (lac/ cmm)

\begin{tabular}{|c|c|c|c|}
\hline & $\begin{array}{c}\text { Mild } \\
\text { preeclampsia }\end{array}$ & $\begin{array}{c}\text { Severe } \\
\text { preeclampsia }\end{array}$ & Eclampsia \\
\hline Lakshmi VC[9] & $2.1 \pm 0.5$ & $0.8 \pm 0.3$ & $0.7 \pm 0.3$ \\
\hline Chauhan P[10] & $1.73 \pm 0.25$ & $1.45 \pm 0.24$ & $1.21 \pm 0.22$ \\
\hline MohapatraS[11] & $2.23 \pm 0.19$ & $1.82 \pm 0.45$ & $1.21 \pm 0.49$ \\
\hline Sarkar PD[12] & $1.98 \pm 0.41$ & $1.47 \pm 0.32$ & - \\
\hline Mirza AB[13] & $1.81 \pm 0.52$ & $1.05 \pm 0.64$ & - \\
\hline Kulkarni[14] & 1.84 & 1.19 & 1.18 \\
\hline Present study & $2.35 \pm 0.54$ & $1.24 \pm 0.73$ & $0.86 \pm 0.45$ \\
\hline
\end{tabular}

Table 10: Comparative studies on significant difference of coagulation profile between control and study group.

\begin{tabular}{|l|l|l|l|}
\hline & $\begin{array}{l}\text { Platelet } \\
\text { count }\end{array}$ & PT & APTT \\
\hline Naaz A[4] & $<0.01$ & $<0.001$ & $<0.0001$ \\
\hline Chauhan P[10] & $<0.001$ & $>0.05$ & $>0.05$ \\
\hline Priyadarshini G[15] & $<0.001$ & $<0.05$ & $<0.001$ \\
\hline Present study & $<0.001$ & $<0.001$ & $<0.001$ \\
\hline
\end{tabular}

Table 11: Comparative study of $\%$ of thrombocytopenia in different categories of PIH

\begin{tabular}{|l|l|l|}
\hline & Joshi SR[16] & Present study \\
\hline Control & - & $1 \%$ \\
\hline mild preeclampsia & $3.4 \%$ & $7.5 \%$ \\
\hline severe preeclampsia & $43.7 \%$ & $57 \%$ \\
\hline Eclampsia & $55 \%$ & $100 \%$ \\
\hline
\end{tabular}

Even though the mean values of PT and APTT in each group were within normal range there was 
statistical difference between values of case and control.

Total thrombocytopenia cases were $31 \%$ in present study and $24.54 \%$ in study of Joshi SR ${ }^{[16]}$. In present study, gestational hypertension group no patient had thrombocytopenia. All cases with platelet count $<1.0 \mathrm{lac} / \mathrm{cmm}$ belong to severe preeclampsia and eclampsia group. Leduc et al ${ }^{[3]}$ observed thrombocytopenia in $20 \%$ cases of severe preeclampsia, Metz et al ${ }^{[17]}$ observed thrombocytopenia in $4 \%$ and $7 \%$ cases of mild and severe preeclampsia respectively, Mary pat Fitzgerald et al ${ }^{[18]}$ reported thrombocytopenia ranging from 11-29\% in preeclampsia and Mbanya et al ${ }^{[15]}$ reported $8.9 \%$ prevalence of thrombocytopenia in preeclampsia.

No cases had prolonged PT or APTT in control group in present study. Among study group 13cases had prolongation of PT and 3 cases had prolongation of APTT. It was observed that prolongation of PT or APTT was never seen with normal platelet count. Out of 13 PT cases 5 had platelet count between 1-1.5 lac while remaining 8 had $<0.5$ lac platelet count whereas all 3 cases of prolonged APTT had thrombocytopenia $<0.5$ lac. Thus prolongation of PT and APTT was significantly correlated with degree of thrombocytopenia with $\mathrm{p}$ value of $<0.05$ in present study. Similar findings were documented by Leduc L ${ }^{[3]}$, Sharma K ${ }^{[5]}$, Priyadarshini G ${ }^{[7]}$, Nirmal $\mathrm{T}^{[8]}$, S Mohapatra [11], Metz $\mathrm{J}^{[17]}$ and FitzGerald MP ${ }^{[18] .}$

However majority of cases of low platelet count had PT and APTT within normal range.

\section{Limitations of the study:}

Equal number of control and each subgroup of cases could not be included. Similarly equal numbers of cases in each subgroup were not available for comparison.

Cases of PIH could not be followed up so exact measure of severity and maternal and fetal outcome are not known.

\section{CONCLUSION}

Platelet count, PT and APTT were never found abnormal in $3^{\text {rd }}$ trimester normal pregnant women.

However in PIH, platelet count was decreased in $7.5 \%$ cases of mild preeclampsia, $57 \%$ cases of severe preeclampsia and $100 \%$ cases of eclampsia. PT was prolonged in $28 \%$ cases of severe preeclampsia and $37.5 \%$ cases of eclampsia. APTT was prolonged in $2.8 \%$ cases of severe preeclampsia and $25 \%$ cases of eclampsia.

Degree of thrombocytopenia significantly increases with increasing severity of the disease.PT and APTT are increased significantly as compared to control group but do not differ significantly with severity of $\mathrm{PIH}$ and are prolonged only in cases of thrombocytopenia.

The mean values of PT and APTT fall in normal range in all groups but increased as severity increased from lower limit to upper limit of normal. So gradual increase of PT and APTT in pregnant female measured by repeated testing may point towards the possibility of PIH and can help in early detection.

\section{REFERENCES}

1. DuttaDC.Text book of obstetrics. $6^{\text {th }}$ ed. Calcutta, India: New Central BookAgency; 2004:221-242.

2. Sibai BM, GabbeSG,NiebyJR,Simpson JL. Obstetrics: Normal and Problem Pregnancies. $\quad 3{ }^{\text {rd }} \mathrm{Ed}$. New York: Churchill Livingstone; 1996: 935-991.

3. Leduc L, Wheeler JM, Kirshon B, Mitchell $\mathrm{P}$, Cottan DB. Coagulation profile in severe preeclampsia.ObstetGynecol,1992 Jan;79(1):14-8.

4. Naaz A, PadugupatiS, Sarma, SushmaP. A Study on Coagulation Profile in Pregnancy Induced Hypertension Cases. IOSR Journal of Biotechnology and Biochemistry. Sep. - Oct. 2015;1(6): 82-88.

5. Sharma SK, Philip J,Whitten CW, Padakandla UB, Landers DF. Assessment of changes in coagulation in parturients using thromboelastography. American 
society of Anaesthesiologistinc, 1999, vol. 90,385-390.

6. Prakash J, Pandey LK, Singh AK, Kar B. Hypertension in pregnancy: Hospital based study. J Assoc Physicians India 2006;54:273

7. Priyadarshini G, MohantyRR. Assessment of Coagulation Profile and its Correlation with Severity of Preeclampsia in Women of Odisha. International Journal of Physiology 2014;3 (1), 135-140.

8. Nirmala T, Kumar P. Study of coagulation profile in PIH. Indian Journal of Pathology and Oncology. 2015;2(1);1-6.

9. Lakshmi CV. Comparative Study of Coagulation Profile in Mild Pre-eclampsia, Severe Pre-eclampsia, and Eclampsia. Int J Sci Stud 2016;4(4):180-183.

10. ChauhanP,Rawat U, Bisht V, Purohit RC. Comparison of Coagulation Profile in PreEclamptic and Eclamptic Patients with Normotensive Pregnant Patients. Journal of Evolution of Medical and Dental Sciences. 2014;3:3208- 3215.

11. Mohapatra S, PradhanBB, SatpathyU K, Mohanty A,PattnaikJ R. Platelet estimation: Its prognostic value in pregnancy induced hypertension. Indian J PhysiolPharmacol 2007; 51(2): 160-164.

12. Sarkar PD, Sogani S. Association of antithrombin-III and platelet count with pregnancy induced hypertension. Int $\mathbf{J}$ Reprod Contracept Obstet Gynecol. 2013;2:398-401.

13. Mirza AB. Coagulation Profiles in $\mathrm{PIH}-\mathrm{a}$ ) To Determine Coagulation Index to Distinguish Severe Preeclampsia from Normal Pregnancy b) To Assess the Correlation of Coagulation Parameters in Normal Pregnancy \& in Varying Grades of Preeclampsia. International Journal of Science and Research. August 2015; 4 (8):387-90.
14. Kulkarni RD, Sutaria UD. Platelet count in toxaemias of pregnancy. J ObstetGynecol. India 1983; 33:321-25.

15. Mbanya D, TayouTagny C, Takoeta E, Mbu R, KaptueL.Factors associated with thrombocytopenia amongpregnant women in Cameroon. Sante2007; 17(4):213-7.

16. Joshi SR, Tekwani DT, Bihade A, Joshi R, Murley D. Study of coagulation profile in pregnancy induced hypertension. MedPulse - International Medical Journal. 2015; 2:299-302.

17. Metz J, Cincotta R, Francis M, DeRosa L, Balloch A. Screening for consumptive coagulopathy in preeclampsia.Int $\mathbf{J}$ GynaecolObstet, 1994 Jul; 46(1):3-9.

18. FitzGerald MP, Floro C, Siegel J, Hernandez E. Laboratory findings in hypertensive disorders of pregnancy. J Natl Med Assoc1996 Dec;88(12):794-8. 